\title{
Microhardness and Biocompatibility of Silicon Nitride Ceramic Developed for Dental Applications
}

\author{
Rayaa Wananuruksawong1,2, Thanakorn Wasanapiarnpong1,2, Nirada Dhanesuan ${ }^{3}$, \\ Pavinee Padipatvuthikul Didron ${ }^{3 *}$ \\ ${ }^{1}$ Research Unit of Advanced Ceramic, Department of Materials Science, Faculty of Science, Chulalongkorn \\ University, Bangkok, Thailand \\ ${ }^{2}$ National Center of Excellence for Petroleum, Petrochemical, and Advanced Material, Chulalongkorn University, \\ Bangkok, Thailand \\ ${ }^{3}$ Faculty of Dentistry, Srinakharinwirot University, Bangkok, Thailand \\ Email: "pavinee.didron@gmail.com
}

Received 23 September 2014; revised 20 October 2014; accepted 10 November 2014

Copyright (C) 2014 by authors and Scientific Research Publishing Inc.

This work is licensed under the Creative Commons Attribution International License (CC BY).

http://creativecommons.org/licenses/by/4.0/

(c) (i) Open Access

\section{Abstract}

Silicon nitride $\left(\mathrm{Si}_{3} \mathrm{~N}_{4}\right)$ ceramic is an attractive material for dental applications, especially used as a dental core material, due to its unique properties including high fracture toughness, high strength, high wear resistance and non-cytotoxicity. In this study, the $\mathrm{Si}_{3} \mathrm{~N}_{4}$ ceramic was fabricated by a non-pressure sintering technique at a relatively low sintering temperature of $1650^{\circ} \mathrm{C}$ in nitrogen atmosphere. Borosilicate glass and $5 \mathrm{wt} \% \mathrm{ZrO}_{2}$-added borosilicate glass were used for coating on the $\mathrm{Si}_{3} \mathrm{~N}_{4}$ core surface because of their compatibility in thermal expansion, high chemical resistance and bio-inert. The specimens were then fired in electric tube furnace at $1100^{\circ} \mathrm{C}$. The Vickers microhardness of borosilicate glass and $5 \mathrm{wt} \% \mathrm{ZrO}_{2}$-added borosilicate glass veneering materials were measured and compared with the commercial dental veneer porcelain as a control (VITA VMK 95). The cytotoxicity of the $\mathrm{Si}_{3} \mathrm{~N}_{4}$ ceramic and the veneering materials were tested by MTT assay, using human gingival fibroblasts (HGF) and periodontal ligament fibroblasts (HPDLF). The results indicate that the $\mathrm{Si}_{3} \mathrm{~N}_{4}$ ceramic and $\mathrm{Si}_{3} \mathrm{~N}_{4}$ ceramic veneered with borosilicate glass or $5 \mathrm{wt} \%$ $\mathrm{ZrO}_{2}$-added borosilicate glass veneering materials tested in this study are not toxic to oral tissue and can be used to produce dental prostheses.

\section{Keywords}

Silicon Nitride, Ceramic, Microhardness, Biocompatibility, Dentalcore

\footnotetext{
"Corresponding author.
}

How to cite this paper: Wananuruksawong, R., et al. (2014) Microhardness and Biocompatibility of Silicon Nitride Ceramic Developed for Dental Applications. Materials Sciences and Applications, 5, 1034-1039. 


\section{Introduction}

Silicon Nitride $\mathrm{Si}_{3} \mathrm{~N}_{4}$ ceramic has long been used for various engineering applications to produce cutting tools, components of engine, bearing, etc. It possesses unique properties of high fracture toughness, strength, hardness and wear resistance. In addition, because of its excellent physicochemical behavior and biocompatibility, it has been used to fabricate orthopedic and prosthetic implants such as knee and hip-joint replacements [1]. $\mathrm{Si}_{3} \mathrm{~N}_{4}$ ceramic also has chemical stability and good wetting properties [2] which positively affect the adhesion of the core-veneer interface and lead to higher strength of the material.

Over the past several years, dental prosthesis has been made of metals such as gold alloy, palladium alloy, titanium alloy, nickel-chromium alloy, etc. A problem occurs because metal ion released from these alloys may react with oral tissue and saliva. Dental patients therefore can be affected from toxic metal oxides and metal alloy allergies that resulted in inflammation, swelling and bleeding of oral tissue [3]. Another drawback is the undesirable metallic color of the prosthesis. Since patients have now become more concerned about aesthetic, the demand of non-cytotoxic and natural-looking aesthetic restorations has tremendously increased. All-ceramic restorations thus have been developed for these aesthetic requirements.

Although lacks of long-term stability, Yttria-stabilized zirconia is the material commonly used to produce dental prosthesis for aesthetic purposes, due to its appearance, high strength and high fracture toughness. Several reports indicated that the water radicals penetrate the interior zirconia lattice in humid atmosphere [4], resulting in the formation of tensile stress in surface grains. This leads to destabilization of the tetragonal phase [5] and greater risk of failure in the long term. $\mathrm{Si}_{3} \mathrm{~N}_{4}$ ceramics are more reliable than zirconia in term of its structure and thus they are preferred candidates for many applications in industrial engineering [4]. However, so far $\mathrm{Si}_{3} \mathrm{~N}_{4}$ ceramics have not been studied or used as a material for dental applications.

The authors have achieved the white color and high density $\mathrm{Si}_{3} \mathrm{~N}_{4}$ ceramic by pressureless sintering at $1650^{\circ} \mathrm{C}$ in nitrogen atmosphere [6]. The white $\mathrm{Si}_{3} \mathrm{~N}_{4}$ ceramic obtained through this procedure was aimed to be used as the material to produce dental core, the inner part of the dental crown or bridges which was usually produced by metal alloys. For aesthetic appearance, the dental core must be coated by a veneering material that is compatible in term of the thermal expansion (CTE of the veneering material has to match with the CTE of the core material). Borosilicate glass was therefore used as the veneering material since it has a compatible thermal expansion with silicon nitride ceramic. Furthermore, borosilicate glass posses properties of high chemical resistance and bio-inert, also its color can be easily adjusted by adding metal oxide, hence the shade of prosthesis could be adjusted for each patient. One important thing in real clinical application is the hardness of the dental prosthesis. It has to be comparable to the hardness of natural tooth because the tooth can be damaged when occluding if the prosthesis surface is too hard.

Another significant property of the dental prosthesis is non-cytotoxicity. Several previous reports indicated that silicon nitride ceramic can be used as biomaterial. Silva et al. studied $\mathrm{Si}_{3} \mathrm{~N}_{4}$ implants kept in rabbits' tibias for 8 weeks and found that the rabbits' bone could be formed around $\mathrm{Si}_{3} \mathrm{~N}_{4}$ implants [7]. Kue et al. studied the biocompatibility of the polished and unpolished $\mathrm{Si}_{3} \mathrm{~N}_{4}$ in an in vitro model using the human osteoblast-like MG-63 cell line. The polished $\mathrm{Si}_{3} \mathrm{~N}_{4}$ was found to support the bone cell growth and metabolism [8]. Thus, $\mathrm{Si}_{3} \mathrm{~N}_{4}$ implants have been confirmed as non-toxic for clinical use. However, there has been so far no study of the biocompatibility and cytotoxicity of $\mathrm{Si}_{3} \mathrm{~N}_{4}$ to oral tissue.

The objectives of this study were to investigate the surface microhardness of the $\mathrm{Si}_{3} \mathrm{~N}_{4}$ ceramic coated with borosilicate glass and $5 \mathrm{wt} \% \mathrm{ZrO}_{2}$-added borosilicate glass veneer materials and the biocompatibility of $\mathrm{Si}_{3} \mathrm{~N}_{4}$ ceramic and $\mathrm{Si}_{3} \mathrm{~N}_{4}$ ceramic coated with borosilicate glass specimens by MTT assay cytotoxicity testing, using human gingival fibroblasts and periodontal ligament fibroblasts (HGF and HPDLF) cell culture.

\section{Materials and Methods}

\subsection{Preparation of $\mathrm{Si}_{3} \mathrm{~N}_{4}$ Discs}

The starting materials consist of high purity $\alpha-\mathrm{Si}_{3} \mathrm{~N}_{4}$ powders (particle size $0.8 \mu \mathrm{m}$, SN E-10 grade, Ube Industries, Japan) with $\mathrm{Y}_{2} \mathrm{O}_{3}$ (RU, Shin Etsu Chemical, Japan), $\mathrm{SiO}_{2}$ (KE-P30, Nippon Shokubai, Japan), and MgO (MJ-30, surface area $31.7 \mathrm{~m}^{2} / \mathrm{g}$, Iwatani Chemicals, Japan) as sintering aids. The weight ratio of silica:magnesia: yttria is 3:3:5. The mixture was ball-milled using ethanol (99.9\%) as a medium for 24 hours in a polyethylene bottle with silicon nitride balls (SUN-12, diameter $5 \mathrm{~mm}$, Nikkato Corporation, Japan). Subsequently, the mix- 
ture was added in Polyvinylbutyral (PVB 630, mineral 75\% and viscosity 50 - 70 cP) by 1 wt\%. The homogenized mixture was dried at $60^{\circ} \mathrm{C}$ in rotary evaporator and was then sieved through a 100 -mesh sieve. The mix powder was formed by hydraulic pressing at $50 \mathrm{MPa}$ and binder burnout at $600^{\circ} \mathrm{C}$ for $1 \mathrm{~h}$ in air. Specimens were pre-sintered in a $\mathrm{BN}$ crucible at $1450^{\circ} \mathrm{C}$ for $2 \mathrm{~h}$ under $1 \mathrm{~atm}$ of $\mathrm{N}_{2}$ gas flow (2 l/min) in order to find an appropriate hardness before being machined into artificial dental core shape. Subsequently, the machined specimen was sintered again at $1650^{\circ} \mathrm{C}$ for $2 \mathrm{~h}$ in nitrogen atmosphere. Sintered $\mathrm{Si}_{3} \mathrm{~N}_{4}$ discs were measured the bulk density by the Archimedes method using water.

\subsection{Preparation of Veneering Materials}

Borosilicate glass ( $<150$ micrometer, Pyrex) was mixed with $5 \mathrm{wt} \%$ of zirconia powder ( $3 \mathrm{wt} \% \mathrm{Y}_{2} \mathrm{O}_{3}$-partial stabilized zirconia) and $30 \mathrm{wt} \%$ of polyvinyl alcohol (5 wt\% solution) into paste. The prepared paste was painted onto the specimens' surface. Then the specimens were fired by electric tube furnace in air at $1100^{\circ} \mathrm{C}$.

\subsection{Surface Microhardness Test}

Three veneering materials were subjected to microhardness measurement; VMK (control), borosilicate glass, and $5 \mathrm{wt} \% \mathrm{ZrO}_{2}$-added borosilicate glass). The Vickers' hardness values of each specimen were measured with a microhardness tester (Micromet II, Buehler, Lake Bluff, IL, USA) using a Vickers’ diamond tip under a $0.2 \mathrm{~kg}$ indentation load for $15 \mathrm{~s}$ [9]. Five indentations per specimen were obtained on the top surface. The Vickers' hardness values were then calculated using the following formula,

$$
H V=\frac{1.8544(9.807 P)}{d^{2}}
$$

$H V$ is the Vickers hardness value, $P$ is the indentation load and $d$ is the average diagonal length that calculated by the two diagonal lengths of the indentation. An average value of each specimen was calculated and subjected to statistical analysis.

\subsection{Cell Culture and Reagents}

Human gingival and periodontal ligament fibroblasts (HGF and HPDLF) were obtained from extracted caries-free third molars with the patients' informed consent, at the Faculty of Dentistry, Srinakharinwirot University, Thailand. The teeth were washed with $70 \%$ ethanol and sterile phosphate buffer saline (PBS). The gingival tissues were gently removed from cervical area and the periodontal tissues were scraped from middle third of the roots by sterile surgical blades. They were cultivated in Dulbecco's modified eagle medium (DMEM) (Thermoscientific, USA) supplemented with 10\% fetal calf serum (DMEM-FCS), $2 \mathrm{mM}$ L-glutamine, $100 \mathrm{IU} / \mathrm{ml}$ penicillin G, $100 \mathrm{IU} / \mathrm{ml}$ streptomycin. The media supplements were from Invitrogen, USA. Cultures were maintained at $37^{\circ} \mathrm{C}$ in $5 \% \mathrm{CO}_{2}$. After the outgrowth cells reached confluence, they were subcultured into new culture dishes. HGF and HPDLF from passage 3 - 5 were used in the experiments. MTT (3-(4,5-Dimethylthiazol-2yl)-2,5-diphenyltetrazolium bromide) was from Sigma, USA.

\subsection{Cytotoxicity Testing by MTT Assay}

Cells (150,000 per well) were plated in 6-well-plates in DMEM-FCS in the presence of 6 types of ceramic discs (blank: control, VMK: veneer (standard), $\mathrm{ZrO}_{2}$ : core (standard), borosilicate glass: veneer, $5 \mathrm{wt} \% \mathrm{ZrO}_{2}$-added borosilicate glass: veneer and $\mathrm{Si}_{3} \mathrm{~N}_{4}$ : core). After 48 hours incubation, photographs were taken and the discs were removed by sterile forcep. The media was changed to fresh DMEM ( $1 \mathrm{ml}$ per well). One hundred $\mu \mathrm{L}$ of MTT solution (5 mg/ml in phosphate buffered saline) was added to each well and incubated for an additional 30 minutes at $37^{\circ} \mathrm{C}$. The media were then discarded and colored formazan product was dissolved in $1 \mathrm{ml}$ of dimethyl sulfoxide (DMSO). The plates were gently shaken for 10 minutes and optical density was read at $550 \mathrm{~nm}$.

\section{Results and Discussion}

The obtained sintered $\mathrm{Si}_{3} \mathrm{~N}_{4}$ discs are shown in Figure 1. The sintered $\mathrm{Si}_{3} \mathrm{~N}_{4}$ ceramic appears in white opaque color thus is appropriate for using as an esthetic dental core material. Average relative density value result of $\mathrm{Si}_{3} \mathrm{~N}_{4}$ discs is more than $95.11 \%$ by Archimedes method. 
The Vicker'smicrohardness results of $\mathrm{Si}_{3} \mathrm{~N}_{4}$ ceramic coated with veneering materials are shown in Table 1 . The Vickers hardness values of borosilicate glass and $5 \mathrm{wt} \% \mathrm{ZrO}_{2}$-added borosilicate glass are similar to that of VMK which is the commonly used commercial veneering material. All these values are within the range of the hardness of human enamel (3 - 5 GPa) [10].

The cytotoxicity test results of the specimens are illustrated in Figure 2 and Figure 3. There is no statistically difference between cell retrieved from the control and from the tested specimens (VMK: veneer (standard), $\mathrm{ZrO}_{2}$ : core (standard), borosilicate glass: veneer, $5 \mathrm{wt} \% \mathrm{ZrO}_{2}$-added borosilicate glass: veneer and $\mathrm{Si}_{3} \mathrm{~N}_{4}$ : core). The results from this study therefore indicate that all specimens are non-cytotoxic and biocompatible to human gingival and periodontal tissue.

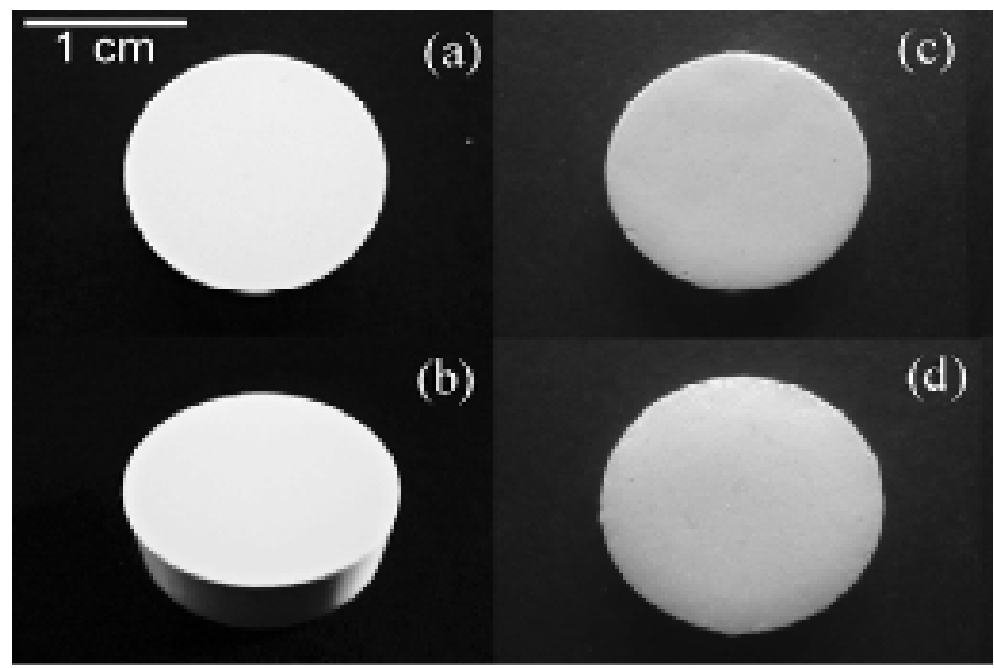

Figure 1. The physical feature of the $\mathrm{Si}_{3} \mathrm{~N}_{4}$ discs sintered at $1650^{\circ} \mathrm{C}$ for $2 \mathrm{~h}$ in top-view (a) and side-view (b), The $\mathrm{Si}_{3} \mathrm{~N}_{4}$ ceramic coated with borosilicate glass through firing at $1100^{\circ} \mathrm{C}$ (c), and The $\mathrm{Si}_{3} \mathrm{~N}_{4}$ ceramic coated with $5 \mathrm{wt} \%$ $\mathrm{ZrO}_{2}$-added borosilicate glass through firing at $1100^{\circ} \mathrm{C}(\mathrm{d})$.

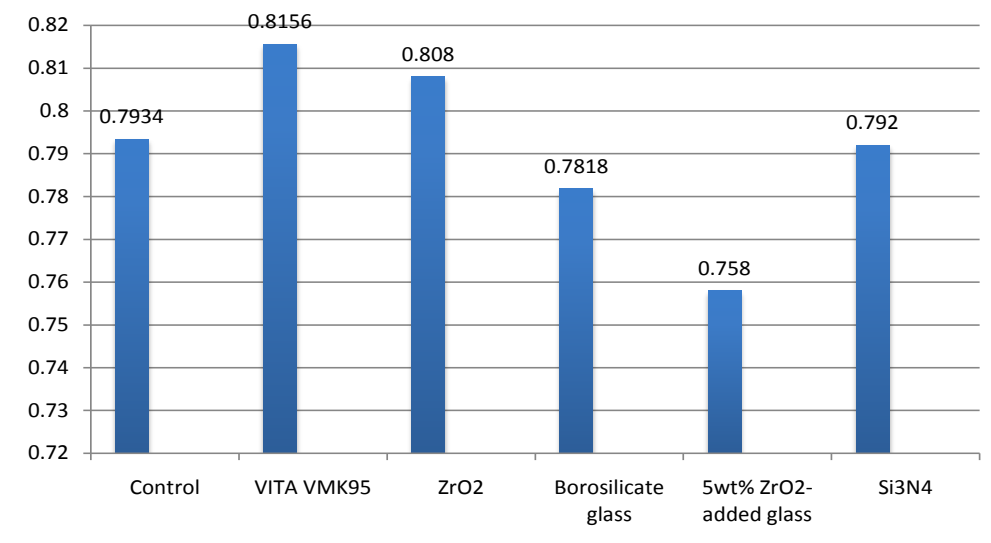

Figure 2. The results of the cytotoxicity test of specimens using human gingival fibroblasts.

Table 1. The Vickers' hardness values of the veneering materials.

\begin{tabular}{cc}
\hline Veneering Materials & Vickers' Hardness (GPa) \\
\hline VITA VMK 95 (Standard) $\left(930^{\circ} \mathrm{C}\right)$ & 4.9 \\
Borosilicate Glass $\left(1100^{\circ} \mathrm{C}\right)$ & 4.2 \\
$5 \mathrm{wt} \% \mathrm{ZrO}_{2}$-added borosilicate glass $\left(1100^{\circ} \mathrm{C}\right)$ & 4.0 \\
\hline
\end{tabular}




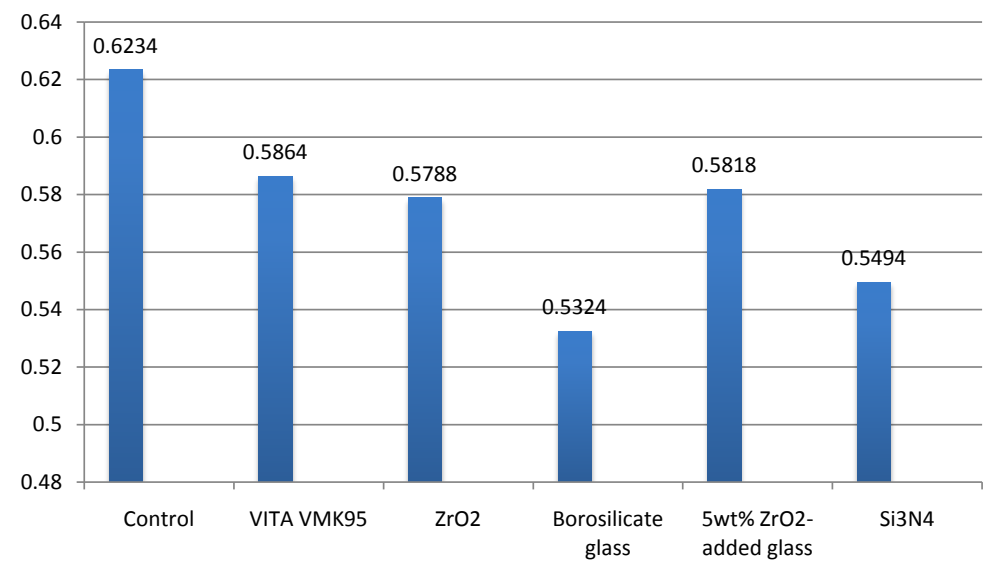

Figure 3. The results of the cytotoxicity test of specimens using human periodontal ligament fibroblasts.

\section{Conclusion}

The white sintered $\mathrm{Si}_{3} \mathrm{~N}_{4}$ can be obtained by pressureless sintering technique at a low sintering temperature of $1650^{\circ} \mathrm{C}$. The borosilicate glass and $5 \mathrm{wt} \% \mathrm{ZrO}_{2}$-added borosilicate glass used as veneering materials have microhardness values within the range of human tooth hardness (3 - $5 \mathrm{GPa}$ ). These values are also similar with the commonly used commercial veneering material, VMK. The results from cytotoxicity test indicate that the sintered $\mathrm{Si}_{3} \mathrm{~N}_{4}$, borosilicate glass veneering material, and $5 \mathrm{wt} \% \mathrm{ZrO}_{2}$-added borosilicate glass veneering material are non-toxic for oral tissue. Therefore, these materials can safely be used to produce dental prostheses.

\section{Acknowledgements}

Authors would like to thank all staffs at the Research Unit of Advanced Ceramic, Department of Materials Science, Chulalongkorn University and all staffs at the Biology Research Laboratory, Faculty of Dentistry, Srinakharinwirot University for all their helps and support. This research was funded partly by Srinakharinwirot University research grant.

\section{References}

[1] Mazzocchi, M. and Bellosi, A. (2008) On the Possibility of Silicon Nitride as a Ceramic for Structural Orthopaedic Implants. Part I: Processing, Microstructure, Mechanical Properties, Cytotoxicity. Journal of Materials Science: Materials in Medicine, 19, 2881-2887. http://dx.doi.org/10.1007/s10856-008-3417-2

[2] Mazzocchi, M., Gardini, D., Traverso, P.L., Faga, M.G. and Bellosi, A. (2008) On the Possibility of Silicon Nitride as a Ceramic for Structural Orthopaedic Implants. Part II: Chemical Stability and Wear Resistance in Body Environment. Journal of Materials Science: Materials in Medicine, 19, 2889-2901. http://dx.doi.org/10.1007/s10856-008-3437-y

[3] Schmalz, G. and Garhammer, P. (2002) Biological Interactions of Dental Cast Alloys with Oral Tissues. Dental Materials, 18, 396-406. http://dx.doi.org/10.1016/S0109-5641(01)00063-X

[4] Chevalier, J. and Gremillard, L. (2009) Ceramics for Medical Applications: A Picture for the Next 20 Years. Journal of the European Ceramic Society, 29, 1245-1255. http://dx.doi.org/10.1016/j.jeurceramsoc.2008.08.025

[5] Schubert, H. and Frey, F. (2005) Stability of Y-TZP during Hydrothermal Treatment: Neutron Experiments and Stability Considerations. Journal of the European Ceramic Society, 25, 1597-1602. http://dx.doi.org/10.1016/j.jeurceramsoc.2004.03.025

[6] Wasanapiarnpong, T., Wada, S., Imai, M. and Yano, T. (2006) Lower Temperature Pressureless Sintering of $\mathrm{Si}_{3} \mathrm{~N}_{4} \mathrm{Ce}-$ ramics Using $\mathrm{SiO}_{2}-\mathrm{MgO}-\mathrm{Y}_{2} \mathrm{O}_{3}$ Additives without Packing Powder. Journal of the Ceramic Society of Japan, 114, 733738. http://dx.doi.org/10.2109/jcersj.114.733

[7] Silva, C., Konig, B., Carbonari, M.J., Yoshimoto, M., Allegrini, S. and Bressiani, J.C. (2008) Bone Growth around Silicon Nitride Implants-An Evaluation by Scanning Electron Microscopy. Materials Characterization, 59, 13391341. http://dx.doi.org/10.1016/j.matchar.2007.11.007

[8] Kue, R., Sohrabi, A., Nagle, D., Frondaza, C. and Hungerford, D. (1999) Enhanced Proliferation and Osteocalcin Pro- 
duction by Human Osteoblast-Like MG63 Cells on Silicon Nitride Ceramic Discs. Biomaterials, 20, 1195-1201. http://dx.doi.org/10.1016/S0142-9612(99)00007-1

[9] Kontonasaki, E., Kantiranis, N., Papadopoulou, L., Chatzistavrou, X., Kavouras, P., Zorba, T., Sivropoulou, A., Chrissafis, K., Paraskevopoulos, K.M. and Koidis, P.T. (2008) Microstructural Characterization and Comparative Evaluation of Physical, Mechanical and Biological Properties of Three Ceramics for Metal-Ceramic Restorations. Dental Materials, 24, 1362-1373. http://dx.doi.org/10.1016/j.dental.2008.03.002

[10] Park, S., Quinn, J.B., Romberg, E. and Arola, D. (2008) On the Brittleness of Enamel and Selected Dental Materials. Dental Materials, 24, 1477-1485. http://dx.doi.org/10.1016/j.dental.2008.03.007 
Scientific Research Publishing (SCIRP) is one of the largest Open Access journal publishers. It is currently publishing more than 200 open access, online, peer-reviewed journals covering a wide range of academic disciplines. SCIRP serves the worldwide academic communities and contributes to the progress and application of science with its publication.

Other selected journals from SCIRP are listed as below. Submit your manuscript to us via either submit@scirp.org or Online Submission Portal.
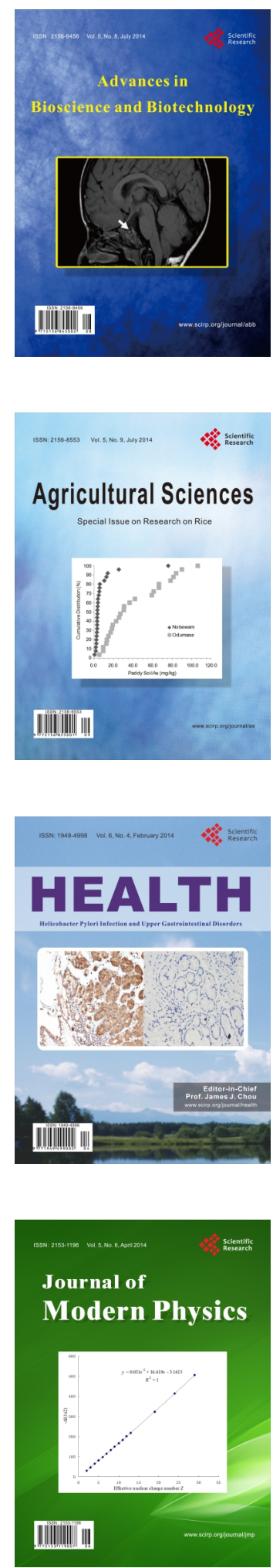
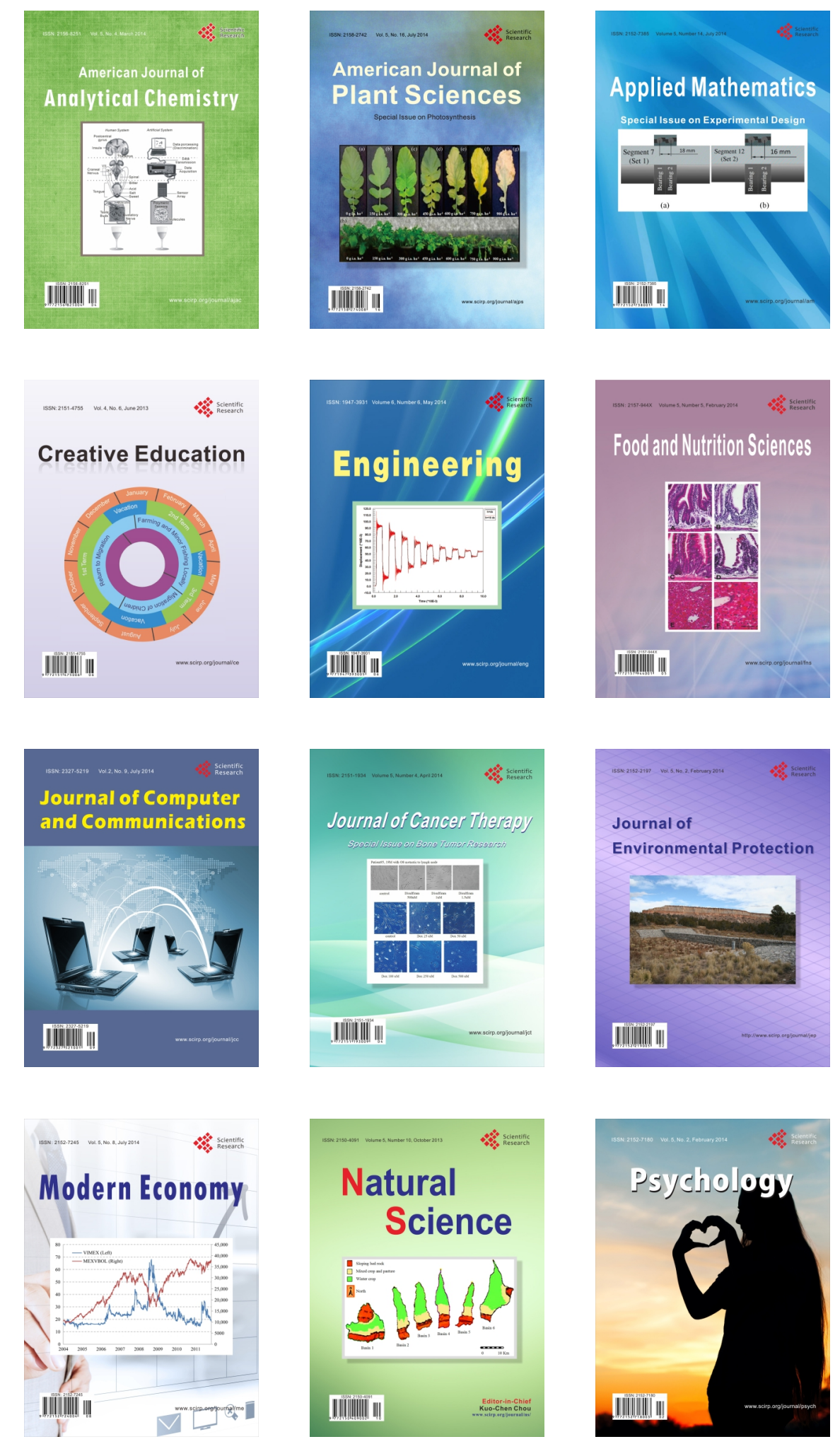